\title{
Heat Treatment in High Chromium White Cast Iron Ti Alloy
}

\author{
Khaled M. Ibrahim and Mervat M. Ibrahim \\ Central Metallurgical R\&D Institute (CMRDI), P.O. Box 87, Helwan, Cairo, Egypt \\ Correspondence should be addressed to Khaled M. Ibrahim; khaledabouelela@yahoo.com \\ Received 3 February 2014; Revised 4 April 2014; Accepted 7 April 2014; Published 29 April 2014 \\ Academic Editor: E. Mittemeijer
}

Copyright (C) 2014 K. M. Ibrahim and M. M. Ibrahim. This is an open access article distributed under the Creative Commons Attribution License, which permits unrestricted use, distribution, and reproduction in any medium, provided the original work is properly cited.

\begin{abstract}
The influence of heat treatment on microstructure and mechanical properties of high chromium white cast iron alloyed with titanium was investigated. The austenitizing temperatures of $980^{\circ} \mathrm{C}$ and $1150^{\circ} \mathrm{C}$ for 1 hour each followed by tempering at $260^{\circ} \mathrm{C}$ for 2 hours have been performed and the effect of these treatments on wear resistance/impact toughness combination is reported. The microstructure of irons austenitized at $1150^{\circ} \mathrm{C}$ showed a fine precipitate of secondary carbides $\left(\mathrm{M}_{6} \mathrm{C}_{23}\right)$ in a matrix of eutectic austenite and eutectic carbides $\left(\mathrm{M}_{7} \mathrm{C}_{3}\right)$. At $980^{\circ} \mathrm{C}$, the structure consisted of spheroidal martensite matrix, small amounts of fine secondary carbides, and eutectic carbides. Titanium carbides $(\mathrm{TiC})$ particles with cuboidal morphology were uniformly distributed in both matrices. Irons austenitized at $980^{\circ} \mathrm{C}$ showed relatively higher tensile strength compared to those austenitized at $1150^{\circ} \mathrm{C}$, while the latter showed higher impact toughness. For both cases, optimum tensile strength was reported for the irons alloyed with $1.31 \% \mathrm{Ti}$, whereas maximum impact toughness was obtained for the irons without Ti-addition. Higher wear resistance was obtained for the samples austenitized at $980^{\circ} \mathrm{C}$ compared to the irons treated at $1150^{\circ} \mathrm{C}$. For both treatments, optimum wear resistance was obtained with $1.3 \%$ Ti.
\end{abstract}

\section{Introduction}

High chromium cast iron is one of the wear resistant materials used in a variety of applications where stability in an aggressive environmental is a principal requirement. These applications include slurry pumps, brick dies, several pieces of mine drilling equipment, rock machining equipment, and similar areas $[1,2]$. Its competitive position in the market is based on its low production costs and stability of its properties at high temperatures, compared to other wear resistant materials [3]. In the as-cast condition, the microstructure of high chromium molybdenum white iron consists essentially of dendrites of austenite in a matrix of eutectic mixture of austenite and $(\mathrm{Fe}, \mathrm{Cr})_{7} \mathrm{C}_{3}$ carbides $[4$, 5]. For many applications, castings are heat treated prior to service to increase the wear resistance as well as impact toughness. Hardening and tempering are commonly used. The reduction in carbon and chromium contents of the austenite results in substantial transformation of the austenite into martensite upon cooling to room temperature $[6,7]$. The eutectic carbides are generally thought to be unaffected by the destabilization heat treatment $[8,9]$.
As shown in Figure 1, there is an optimum austenitizing temperature to achieve maximum hardness which is diverged for each composition. The austenitizing temperature determines the amount of carbon that remains in solution in the austenite matrix. Too high austenitizing temperature increases the stability of austenite, which in turn obtains higher retained austenite in the structure and consequently reduces hardness. Low austenitizing temperature results in low-C martensite, which in turn reduces both hardness and abrasion resistance. Therefore, the successful heat treatment produces austenite destabilization by precipitation of secondary carbides within the austenite matrix. It is also recommended to temper castings before putting them into the service to restore some toughness in the martensitic matrix and to further relieve residual stresses [10].

Another possible strategy for improving wear resistance and toughness of white iron is to add carbide forming elements such as vanadium, tungsten, niobium, and titanium [11]. In this study titanium is added, where titanium is a strong forming element, since $\mathrm{TiC}$ has a high formation temperature and would be the first phase to precipitate during solidification. Therefore, this paper aims at studying the 


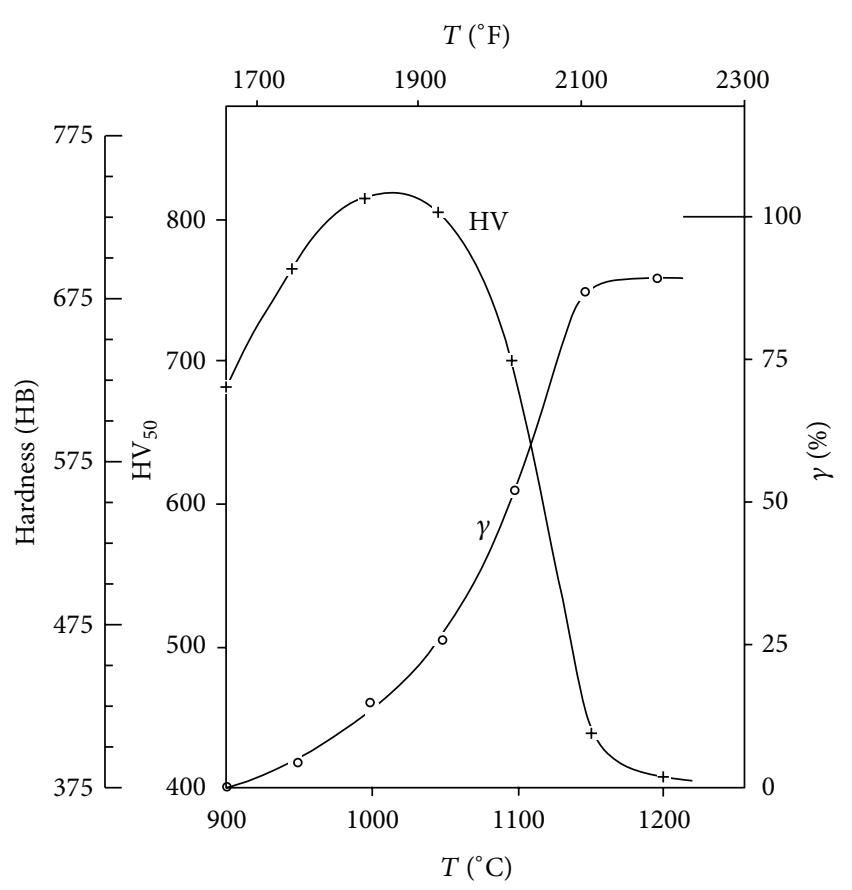

Figure 1: The correlation between the ratio of retained austenite and hardness of a typical high chromium abrasion resistant cast iron [10].

TABLE 1: Chemical composition of the investigated alloys.

\begin{tabular}{lccccc}
\hline $\mathrm{C}$ & $\mathrm{Si}$ & $\mathrm{Mn}$ & $\mathrm{Cr}$ & $\mathrm{Mo}$ & $\mathrm{Ni}$ \\
\hline $2.48 / 2.55$ & $1.33 / 1.52$ & $1.05 / 1.13$ & $15.45 / 16.23$ & $1.25 / 1.36$ & $2.21 / 2.30$ \\
\hline
\end{tabular}

effects of both Ti-additions and heat treatment conditions on microstructure as well as abrasion resistance and impact toughness.

\section{Experimental Work}

The chemical composition of the studied high Cr-Mo white iron is given in Table 1. Sulphur and phosphorous contents were below $0.05 \%$. The alloys were melted in a medium frequency induction furnace. Titanium was added as Fe-Ti $(20 \% \mathrm{Ti})$ to give Ti-contents in the alloys of $0.471,0.93,1.31$, and $1.78 \mathrm{wt} . \%$. The liquid metal was poured at $1520^{\circ} \mathrm{C}$ into chemical bonded sand moulds in the form of tensile and impact specimens.

Two different heat treatment cycles were used; the first one was applied by austenitizing at $980^{\circ} \mathrm{C}$ for one hour and tempering at $260^{\circ} \mathrm{C}$ for $2 \mathrm{hrs}$. The second cycle was performed by austenitizing at $1150^{\circ} \mathrm{C}$ for one hour and tempering also at 260 for $2 \mathrm{hrs}$. Samples for metallographic investigation were polished to a $1 \mu \mathrm{m}$ diamond finish and chemically etched in a freshly prepared solution that contained $1 \mathrm{~g}$ of picric acid and $5 \mathrm{~cm}^{3}$ of hydrochloric acid in $100 \mathrm{~cm}^{3}$ of methanol. The samples were etched for a slightly longer time than would be expected for optical microscope observations. Microstructure investigation was undertaken by light and scanning electron microscopes. Samples measuring

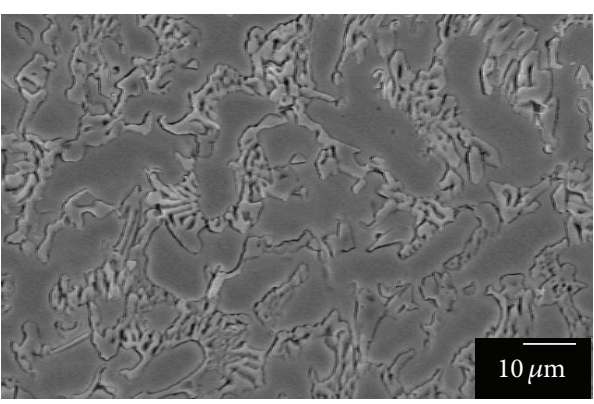

FIGURE 2: Typical microstructure of the as-cast condition with no Ti-addition.

$15 \mathrm{~mm} \times 15 \mathrm{~mm} \times 2.5 \mathrm{~mm}$ were cut using water cooled cutting machine for XRD investigation. The respective $15 \mathrm{~mm}$ square faces were polished to a $1 \mu \mathrm{m}$ diamond finish to remove relatively any mechanical deformed layer at the surface. Xray crystallography was conducted using $\mathrm{Cu}_{\alpha} \mathrm{X}$-ray source. Hardness was measured on Vickers hardness scale with $30 \mathrm{~kg}$ load and a diamond pyramid indentor typical for this scale. Tensile test and Charpy impact test were carried out according to the American Standards ASTM E8 and ASTM E23, respectively. Wear test was carried out on a pin-on-ring type wear testing machine. The test was carried out against 70-mesh $\mathrm{SiC}$ abrasive disc at $65 \mathrm{rpm}$ constant speed under different applied loads of $30,60,110,140$, and $180 \mathrm{~N}$ for 30 minutes each. The samples were weighted before and after the wear test using $0.1 \mathrm{mg}$ precision digital scale to determine the weight loss. The weight loss was taken for two samples as an average for each condition.

\section{Results and Discussion}

3.1. Microstructure. The microstructure of as-cast high chromium white cast iron with no Ti-addition consists of $\mathrm{M}_{7} \mathrm{C}_{3}$ carbides that form during solidification as eutectic phase (a mixture of $\mathrm{M}_{7} \mathrm{C}_{3}$ and austenite) after the formation of proeutectic austenite dendrites (Figure 2). In an earlier study, Ibrahim and Nofal [12] discussed briefly the microstructure of these alloys, with different Ti-additions up to $1.78 \%$, in the as-cast condition. Figure 3 shows SEM for the carbides feature existing in the investigated alloys. In Figure 3(a), the eutectic carbides $\left(\mathrm{M}_{7} \mathrm{C}_{3}\right)$ are distributed in the matrix and $\mathrm{TiC}$ particles are spread either in matrix or over the eutectic chromium carbides [12]. Titanium carbides can also be found stacking close to the eutectic carbides $\mathrm{M}_{7} \mathrm{C}_{3}$ (Figure 3(b)).

The effect of Ti-addition (1.31\% Ti) and austenitizing temperatures on microstructure of the studied irons is shown in Figures 4(a) and 4(b). As seen in Figure 4(a), the samples treated at $980^{\circ} \mathrm{C}$ obtained a microstructure consisting of $\mathrm{M}_{7} \mathrm{C}_{3}$ carbides embedded in martensitic matrix, TiC carbides, small amounts of retained austenite, and also small amount of secondary carbides. The samples austenitized at $1150^{\circ} \mathrm{C}$ showed a structure consisting of a netted eutectic carbides $\left((\mathrm{Cr}, \mathrm{Fe})_{7} \mathrm{C}_{3}, \mathrm{M}_{7} \mathrm{C}_{3}\right)$ embedded in an austenite matrix, secondary carbides, and $\mathrm{TiC}$ particles (Figure $4(\mathrm{~b})$ ). These 


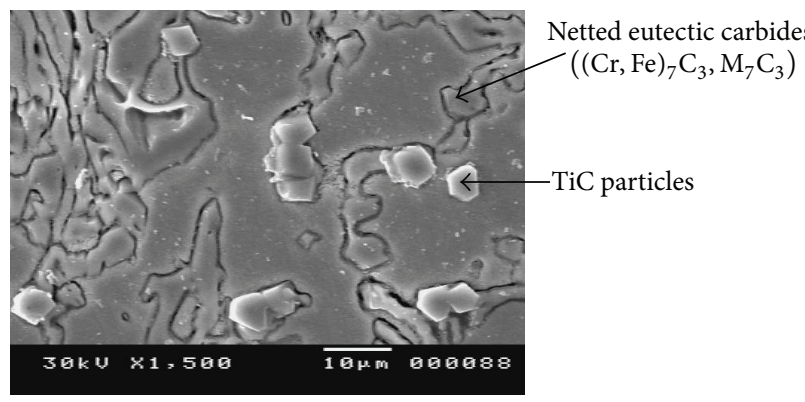

(a)

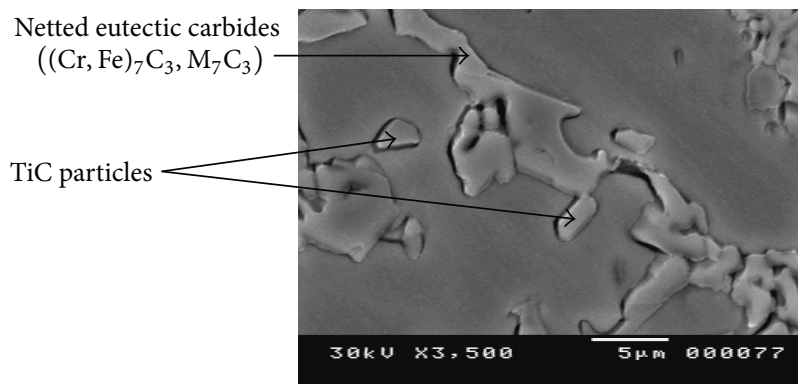

(b)

FIgURE 3: Carbides distribution feature in the investigated high chromium cast irons.

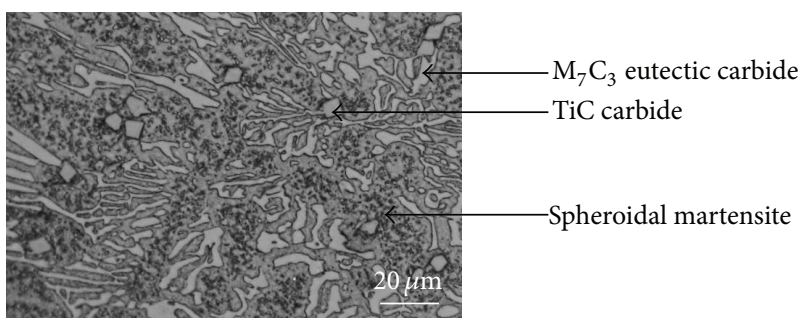

(a)

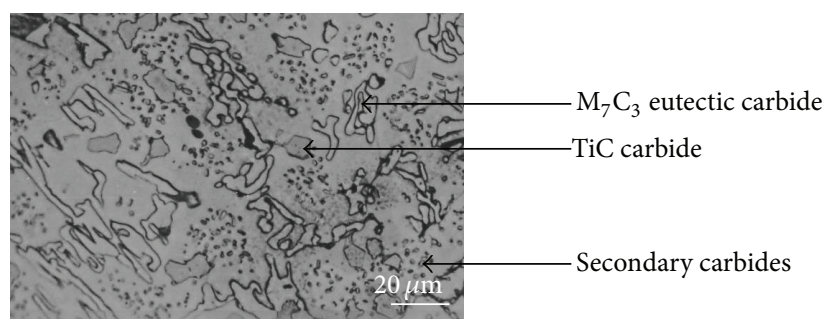

(b)

Figure 4: The microstructure constituents of the alloy contained $1.31 \% \mathrm{Ti}$ and were treated at (a) $980^{\circ} \mathrm{C}$ and (b) $1150^{\circ} \mathrm{C}$.

TiC particles have faceted cuboidal morphology with an average diameter of about 3-4 $\mu \mathrm{m}$. The volume fraction of TiC particles increases with increasing Ti-content in the alloy. The TiC particles are uniformly dispersed throughout the matrix.

The microstructure of the samples treated at $980^{\circ} \mathrm{C}$ for $1 \mathrm{hr}$ shows small amounts of copious fine precipitation of secondary carbides and spheroidal martensite which appears dark in the micrograph (Figure 5). These fine secondary carbides are uniform in size and homogeneously distributed in matrix. They are localized in the austenite grains, where the netted eutectic carbides are essentially unchanged after the heat treatment. The precipitation of secondary carbides from austenite results in decreasing $\mathrm{Cr}$ and $\mathrm{C}$ contents in the austenite. The depletion of both $\mathrm{C}$ and $\mathrm{Cr}$ in the austenite phase will consequently shift the martensite start temperature to a higher level of temperature. Thus, the martensite start temperature will be moved to above room temperature. Therefore during subsequent cooling to ambient temperature, the austenite transforms into martensite. Although a large amount of austenite transforms to martensite after heat treatment, still the iron contains some small amounts of retained austenite.

X-ray diffraction profiles of the investigated alloys after heat treatment comparing with the as-cast condition are shown in Figures 6(a)-6(c). The peaks associated with austenite phase and martensite phase are indicated by $\gamma$ and $\mathrm{M}$, respectively. For example, comparing the results after heat treatment to that for the as-cast, it is seen that the amount of martensite increases markedly while the amount of retained austenite is decreased significantly by applying the heat treatment. In the as-cast condition, the secondary carbides
TABLE 2: X-ray diffraction results for the investigated alloys.

\begin{tabular}{lccc}
\hline$d$-spacing $(\AA)$ & Intensity $(\%)$ & $\sin ^{2} \theta$ & Phase \\
\hline 2.036 & 45.6 & 0.1431 & Carbide \\
2.011 & 17.6 & 0.1431 & Carbide \\
2.080 & 62.0 & 0.1372 & Austenite \\
1.268 & 2.8 & 0.3687 & Eutectic austenite \\
2.073 & 40.7 & 0.1379 & Eutectic austenite \\
0.827 & 2.6 & 0.8677 & Eutectic austenite \\
0.904 & 3.2 & 0.7278 & Austenite \\
\hline
\end{tabular}

cannot be observed because the eutectic carbides $\mathrm{M}_{7} \mathrm{C}_{3}$ are the most formed carbides in the cast condition, while, after treatment, the secondary carbides are more obvious $\left(\mathrm{M}_{23} \mathrm{C}_{6}\right)$. This observation is in agreement with microstructure feature that was obtained in this study (Figures 2 and 5) and also with other studies that were conducted by Carpenter et al. [13] and Vidyorthi et al. [14]. Some crystallographic data from the diffractometer is presented in Table 2. This table shows the $\sin ^{2} \theta$ values obtained for the phase constitutes where $\theta$ is the Bragg angle. The table defines also the $d$-spacing of phase indices. The lattice parameters $a$ and $c$ for the eutectic chromium carbide $(\mathrm{Fe}, \mathrm{Cr})_{7} \mathrm{C}_{3}$ were calculated from the data given in Table 2. This is because this type of carbide $(\mathrm{Fe}$, $\mathrm{Cr})_{7} \mathrm{C}_{3}$ has a hexagonal crystal lattice structure and therefore they are indexed using Miller-Bravais system of coordinates. The values of $a$ and $c$ were 1.394 and $0.452 \mathrm{~nm}$, respectively. In addition, the lattice parameter $a$ of both primary and eutectic austenite was also estimated. It is found that $a$ for primary 


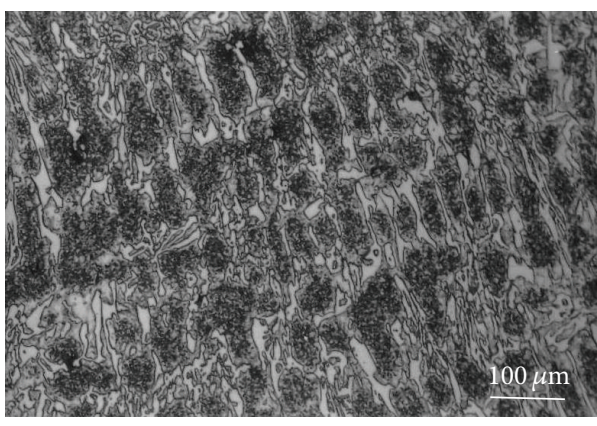

(a)

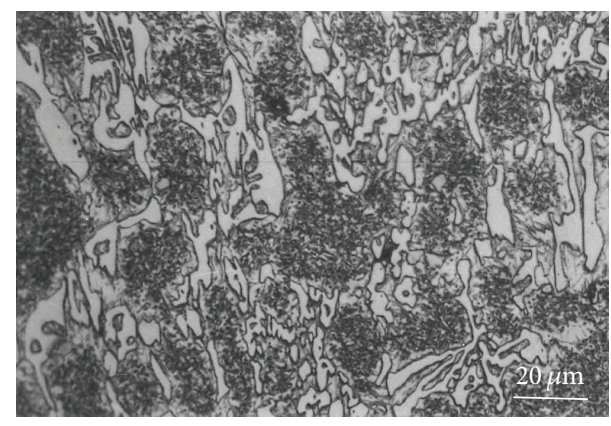

(b)

Figure 5: Microstructure of the martensitic heat treated samples.

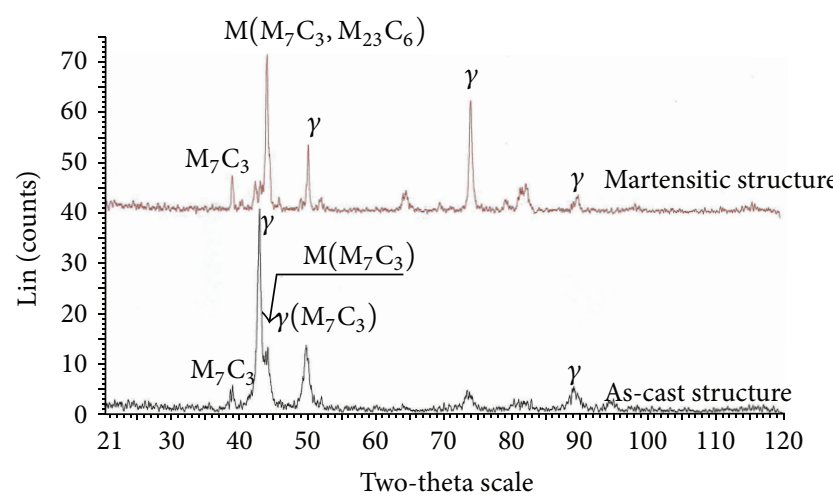

(a)

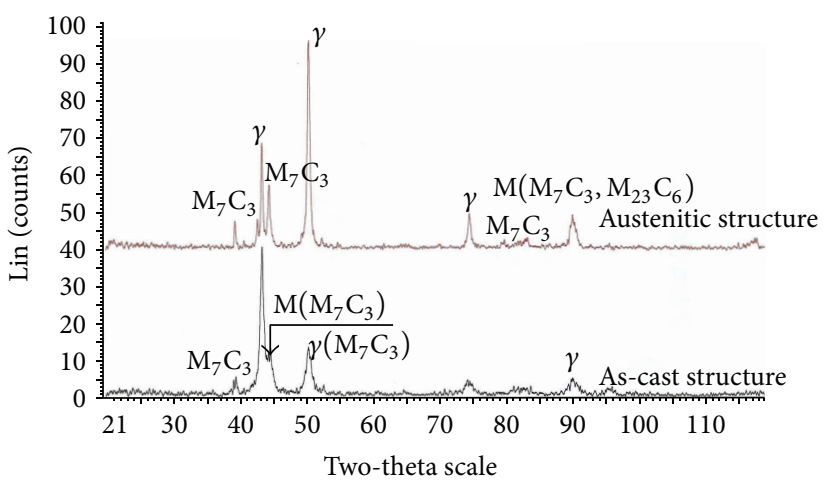

(b)

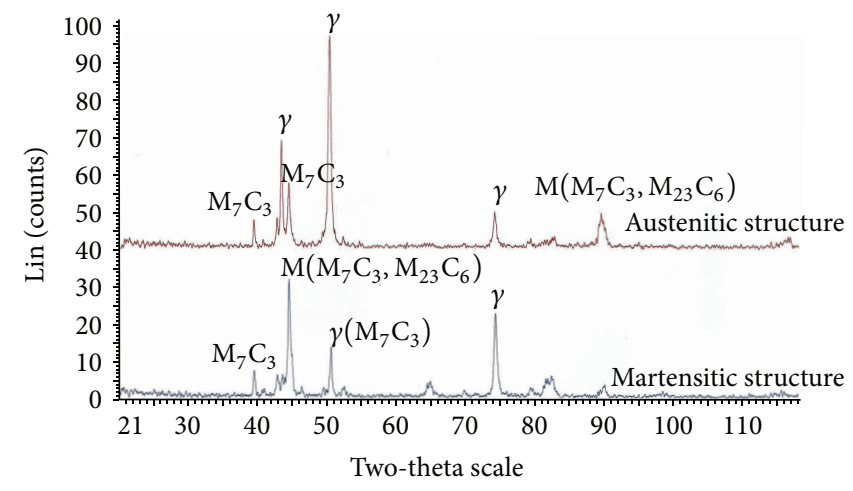

(c)

FIGURE 6: X-ray diffraction profiles of the investigated alloys. (a) Martensitic structure versus the as-cast structure. (b) Austenitic structure versus the as-cast structure. (c) Austenitic structure versus martensitic structure.

and eutectic austenite was found to be 0.361 and $0.359 \mathrm{~nm}$, respectively.

The microstructure of the irons treated at $980^{\circ} \mathrm{C}$ (Figure 7) shows a feature of eutectic $\mathrm{M}_{7} \mathrm{C}_{3}$ carbides embedded in martensitic matrix, TiC carbides, small amounts of retained austenite, and also small amount of secondary carbides. On the other hand, Figure 8 shows the micrographs of heat treated samples at $1150^{\circ} \mathrm{C}$ for $1 \mathrm{hr}$. It shows netted eutectic carbides $\left((\mathrm{Cr}, \mathrm{Fe})_{7} \mathrm{C}_{3}, \mathrm{M}_{7} \mathrm{C}_{3}\right)$ embedded in an austenite matrix. A very fine-scale precipitation of secondary carbides has been formed and localized in the austenite grains as compared to the other samples treated at $980^{\circ} \mathrm{C}$. Moreover, the micrographs show cuboidal particles of $\mathrm{TiC}$ by adding $\mathrm{Ti}$ from $0.47 \%$ to $1.78 \%$. The higher volume fraction and larger size of $\mathrm{TiC}$ were obtained by adding $1.78 \%$ Ti to the iron. Titanium addition resulted also in decreasing the volume fraction of $\mathrm{M}_{7} \mathrm{C}_{3}$ carbides due to migration of a part of carbon to $\mathrm{TiC}$, which indicates that titanium carbides were the first to solidify and may have then acted as nuclei for the proeutectic austenite dendrites, and thereby refining 


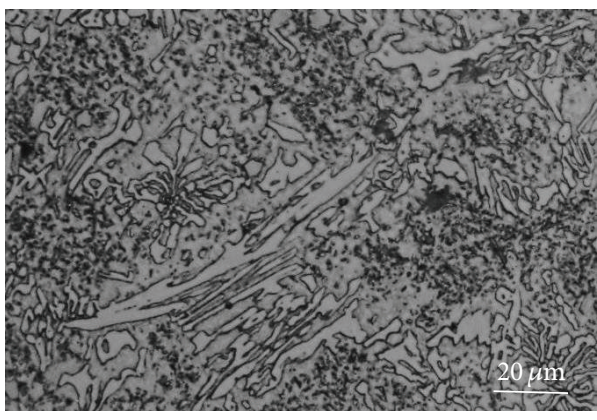

(a)

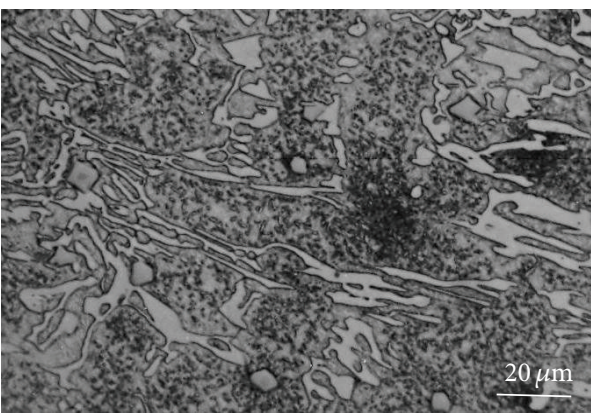

(c)

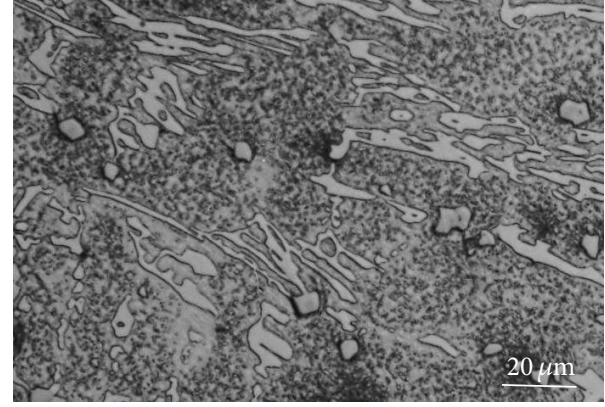

(b)

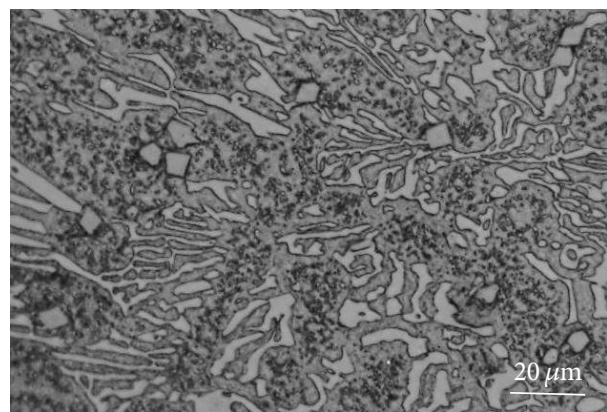

(d)

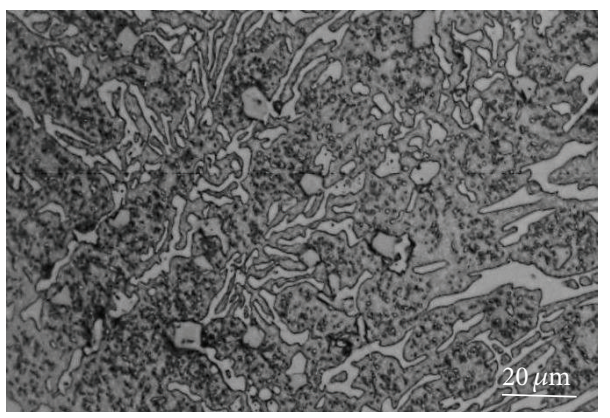

(e)

Figure 7: Effect of Ti-addition on microstructure of the heat treated martensitic irons with (a) $0 \% \mathrm{Ti}$, (b) $0.47 \% \mathrm{Ti}$, (c) $0.93 \% \mathrm{Ti}$, (d) $1.31 \%$ $\mathrm{Ti}$, and (e) $1.78 \% \mathrm{Ti}$.

the structure. Similar studies related to the effect of boron addition on microstructure of white cast iron found that boron refines also the microstructure [15-18].

3.2. Mechanical Properties. Figure 9 shows the effect of both Ti-addition and austenitizing temperature on hardness of the studied white irons. It seems that hardness values are higher for the samples austenitized at $980^{\circ} \mathrm{C}$ compared to the others austenitized at $1150^{\circ} \mathrm{C}$. This is considered a logical phenomenon due to forming of martensitic structure at $980^{\circ} \mathrm{C}$ which is considered a hard phase compared to the austenitic matrix containing secondary carbides that formed at $1150^{\circ} \mathrm{C}$. Farah et al. [19] mentioned in his study for high Cr white cast iron alloyed with $\mathrm{Nb}$ that heat treated martensitic structure obtained higher hardness than the treated austenitic one due to improvement in carbon diffusion in the austenite phase which in turn will transform into higher carbon martensite. This high carbon martensite structure will be harder than the austenitic one. In this study, both heat treated samples (martensitic and austenitic structures) show the same trend for hardness with increasing Ti-additions up to $1.78 \%$. At $980^{\circ} \mathrm{C}$, the increase in hardness was substantial, where it rises from $650 \mathrm{HV}_{30}$ for the base alloy with no Ti-addition to 776 $\mathrm{HV}_{30}$ for the alloy with $1.78 \% \mathrm{Ti}$. On the other hand, at $1150^{\circ} \mathrm{C}$, the samples showed the same trend as the sample treated at $980^{\circ} \mathrm{C}$ but with lower hardness values. At $1150^{\circ} \mathrm{C}$, the base iron with no Ti-addition obtained a hardness value of $510 \mathrm{HV}_{30}$ and it rises to $650 \mathrm{HV}_{30}$ for the iron with $1.78 \% \mathrm{Ti}$.

As shown in Figure 10, the tensile strength of the heat treated samples at $980^{\circ} \mathrm{C}$ and $1150^{\circ} \mathrm{C}$ obtained also the same trend, where the tensile strength increases with increasing $\mathrm{Ti}$ additions up to a maximum value corresponding to $1.31 \% \mathrm{Ti}$ and then decreases with further higher Ti-additions $(1.78 \%$ Ti). Such increase in tensile strength could be attributed to the strengthening effect of the heat treated martensitic or austenitic matrices by homogenously distributed $\mathrm{TiC}$ in 


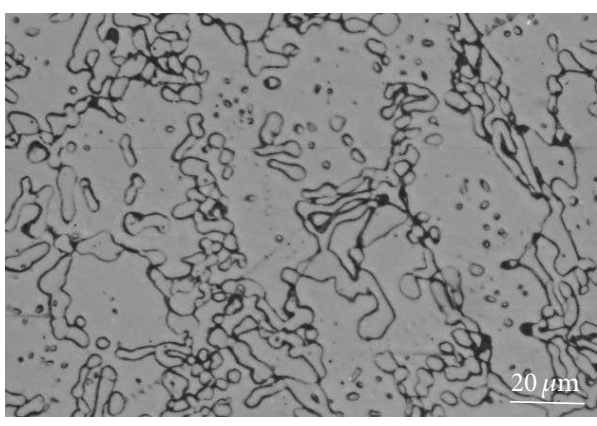

(a)

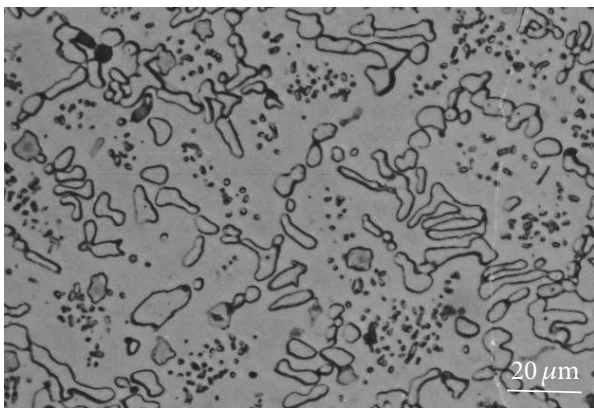

(c)

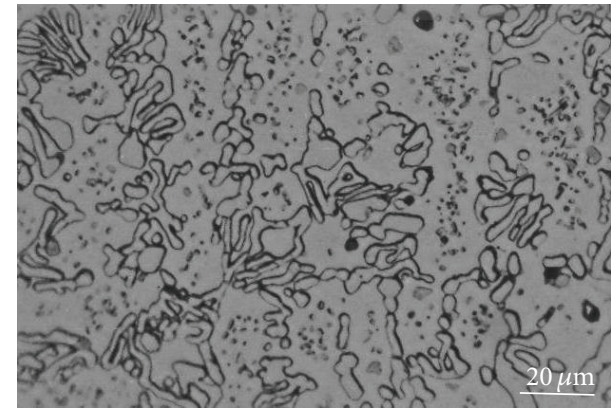

(b)

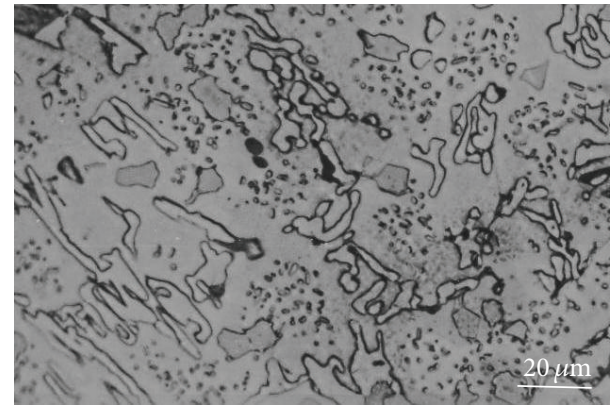

(d)

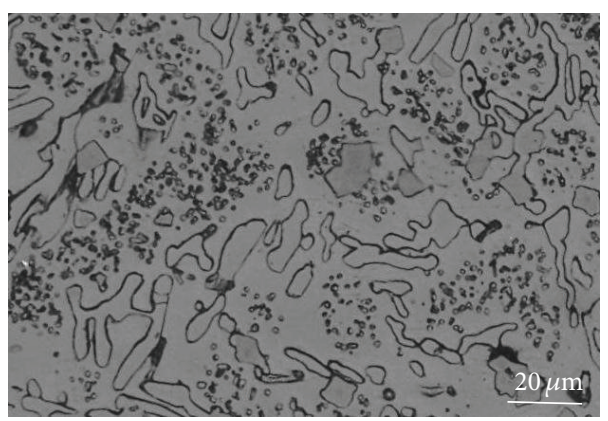

(e)

FIGURE 8: Effect of Ti-addition on microstructure of the heat treated austenitic irons with (a) $0 \% \mathrm{Ti}$, (b) $0.47 \% \mathrm{Ti}$, (c) $0.93 \% \mathrm{Ti}$, (d) $1.31 \% \mathrm{Ti}$, and (e) $1.78 \% \mathrm{Ti}$.

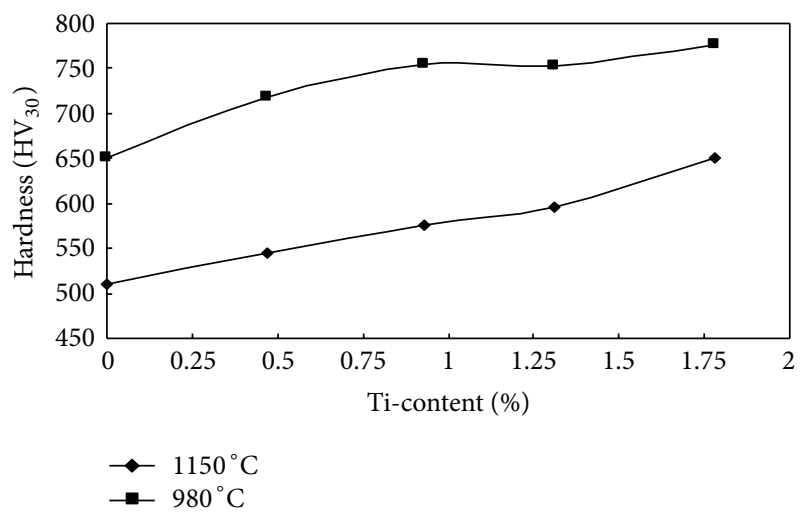

FIgURE 9: Effect of austenitizing temperature and Ti-addition on hardness of the investigated alloys.

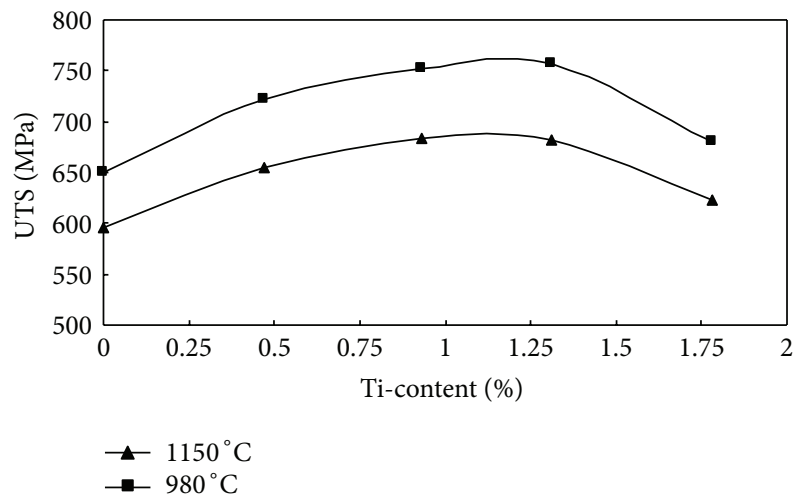

FIgURE 10: Effect of austenitizing temperature and Ti-addition on tensile strength of the investigated alloys. 


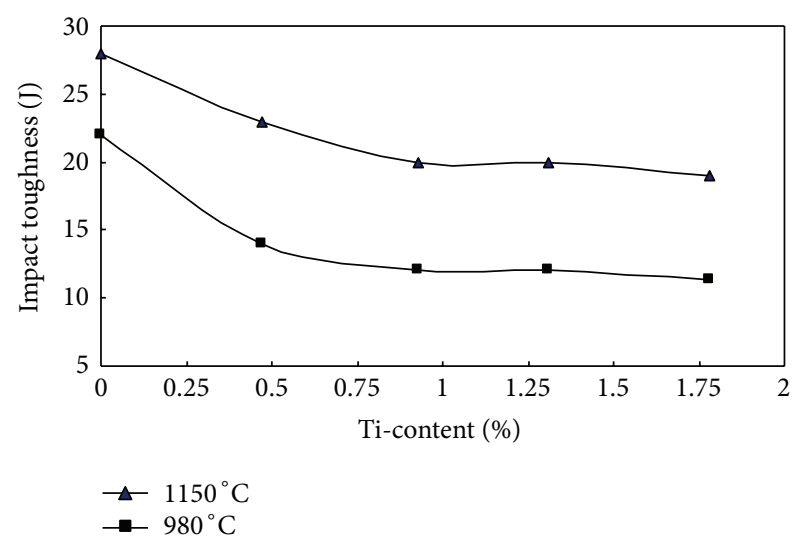

FIGURE 11: Effect of austenitizing temperature and Ti-addition on impact toughness of the investigated alloys.

those matrices. However, a drop in the strength was obtained with further Ti-addition $(1.78 \% \mathrm{Ti})$ due to the clustering effect of $\mathrm{TiC}$ particles in both matrices. In addition, the martensitic matrix showed higher tensile strength compared to the austenitic matrix reinforced with secondary carbides. This is of course related to the nature of the matrices, in which the martensitic matrix is considered harder and has higher strength than the austenitic one.

The results of impact toughness of the studied heat treated unnotched samples are shown in Figure 11. It is obvious that both austenitizing temperatures have the same behaviour with Ti-additions, where the samples without Ti-addition showed the highest impact value and started to decrease gradually to keep with approximately constant values with Ti-additions ranging from $0.93 \%$ to $1.78 \%$. Normally for the metallic materials an increase in tensile strength associated with a decrease in impact toughness, but it is clear here in this study that the white iron alloyed with $\mathrm{Ti}$ in the range of $0.93 \%$ to $1.78 \%$ showed an increase in tensile strength without a decrease in impact toughness. It is suggested that the refinement in structure happened by Ti-addition and also strengthened the matrix by secondary carbides resulting in no loss in the impact toughness. This was obvious for the irons alloyed with $1.78 \% \mathrm{Ti}$, where the reinforcement of matrix with secondary carbides can compensate the deterioration in toughness that happened as a result of forming some locations of TiC agglomeration in matrix. Therefore, in this study the applied heat treatment by austenitizing either at $980^{\circ} \mathrm{C}$ or at $1150^{\circ} \mathrm{C}$ is very beneficial to keep the impact toughness constant specially with higher values of Ti-contents $(>0.93 \%$ Ti). In a similar work done by Bedolla-Jacuinde et al. [11] for studying the effect of Ti-addition (in the range of 0 $2.02 \% \mathrm{Ti}$ ) on wear resistance and fracture toughness of $16 \%$ $\mathrm{Cr}$ white cast iron in the as-cast condition, they noticed that fracture toughness kept almost constant with all ranges of Tiaddition due to the refinement effect of Ti-addition on the microstructure.

High chromium white iron is specially qualified for abrasion resistant applications. The predominant carbides in its structure provide it with a high hardness necessary for

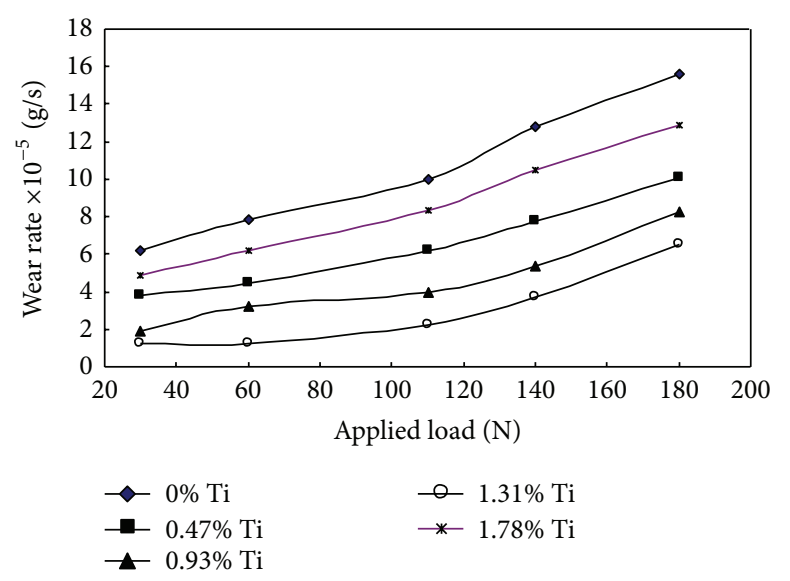

(a)

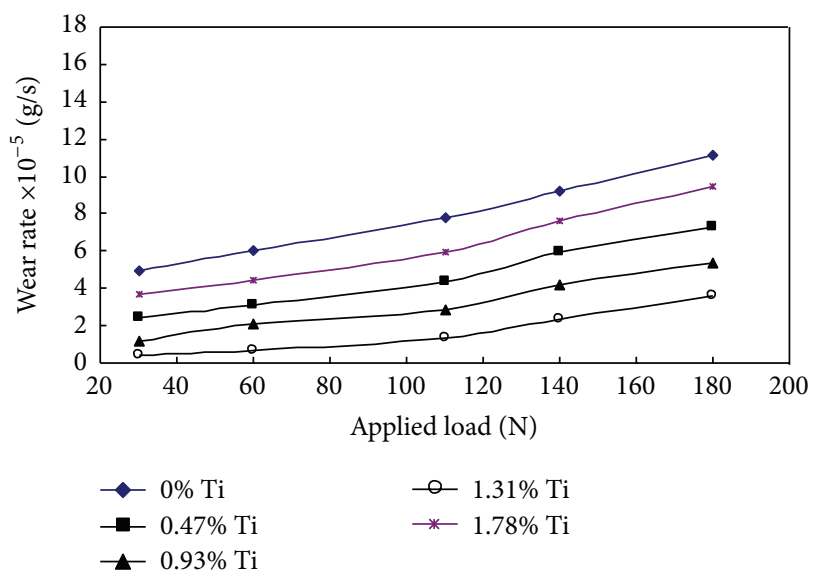

(b)

FIGURE 12: Effect of austenitizing temperature, applied load, and Tiaddition on abrasion wear rate of the investigated alloys treated at (a) $1150^{\circ} \mathrm{C}$ and (b) $980^{\circ} \mathrm{C}$.

crushing and grinding other materials without degradation. Therefore, high chromium white iron is considered a proper choice as a high wear resistant material. Moreover, it can be cast easily into net shapes required for crushing and grinding or handling abrasive materials.

In this investigation, the effects of applied load, austenitizing temperatures, and Ti-additions on abrasion wear of high chromium white iron have been studied, as shown in Figures 12 (a) and 12(b). In both austenitizing temperatures $\left(980^{\circ} \mathrm{C}\right.$ and $1150^{\circ} \mathrm{C}$ ) all samples show the same trend, where wear rate increases with increasing the applied load. This is logical due to the increase in applied shear stress over the worn surface by increasing the applied load. The effect of Ti-addition on wear behaviour of the investigated samples austenitized at $980^{\circ} \mathrm{C}$ and $1150^{\circ} \mathrm{C}$ shows also the same trend, where the wear rate of both structures decreased with increasing Ti-addition up to $1.31 \% \mathrm{Ti}$. This could be attributed to the structure refinement effect, which is corresponding to eutectic structure with mixed chromium carbides and titanium carbides particles achieved by adding $\mathrm{Ti}$ up to $1.31 \% \mathrm{Ti}$. This is in a general agreement with the results reported by Chung et al. [20], 
where they studied the effect of Ti-addition up to $6 \% \mathrm{Ti}$ on wear resistance of $25 \% \mathrm{Cr}-4 \% \mathrm{C}$ white cast iron. They noticed that wear rate decreased with increasing the amount of Tiaddition due to refining the microstructure by Ti-addition. In addition, chromium carbides were replaced by Ti carbides, which are harder than the former. In another study done by Arikan et al. [21] on the effect of Ti-addition up to $0.38 \%$ $\mathrm{Ti}$ on hardness and wear resistance of heat treated $15 \% \mathrm{Cr}-$ $3 \%$ Mo white iron, they observed that wear resistance can be increased by increasing the amount of Ti-addition due to the structure refinement effect. In this study the minimum wear rate was reported for the iron alloyed with $1.31 \% \mathrm{Ti}$ and the maximum one for the iron with no Ti-addition. For the iron alloyed with $1.31 \% \mathrm{Ti}$, massive amount of $\mathrm{TiC}$ particles are homogenously distributed in both martensitic and austenitic matrices. Therefore, it could be concluded here that the optimum Ti-addition should be kept $1.31 \%$ to avoid agglomeration of $\mathrm{TiC}$ in matrix which will weaken the matrix and increase its wear rate. In spite of the fact that the iron contains a high amount of Ti-addition (1.78\%), it gave a high amount of wear rate. This behavior was clear in both heat treatment conditions $\left(980^{\circ} \mathrm{C}\right.$ and $\left.1150^{\circ} \mathrm{C}\right)$. This can be explained by the agglomeration of $\mathrm{TiC}$ particles in certain locations in matrix, where it was easy to pull the carbides out from the matrix and leave cavities. These cavities are considered weak points in matrix and cause in turn higher wear rates. Moreover, these pulled-out particles will insert between the worn surface and the rotating disc causing a third body abrasion wear mechanism which is characterized by high wear rate.

\section{Conclusions}

(1) The samples treated at $980^{\circ} \mathrm{C}$ showed a structure consisting of fine spheroidal martensite, fine precipitation of secondary carbides, small amount of retained austenite, $\mathrm{TiC}$ particles, and eutectic carbides $\left(\mathrm{M}_{7} \mathrm{C}_{3}\right)$.

(2) The samples treated at $1150^{\circ} \mathrm{C}$ showed a structure consisting of fine precipitation of secondary carbides embedded in an austenite matrix, $\mathrm{TiC}$ particles, and eutectic carbides $\left(\mathrm{M}_{7} \mathrm{C}_{3}\right)$.

(3) $\mathrm{TiC}$ particles were well distributed in both heat treated matrices for Ti-additions up to $1.31 \%$ and then started to agglomerate with higher Ti-addition of $1.78 \%$.

(4) Ti-addition caused an increase in hardness due to formation of hard $\mathrm{TiC}$ particles with the $\mathrm{M}_{7} \mathrm{C}_{3}$ carbides as well as the secondary carbides embedded in the heat treated matrices.

(5) Tensile strength and abrasion resistance showed maximum values with $1.31 \% \mathrm{Ti}$ and then these properties were deteriorated with further Ti-addition (1.78\% Ti) due to $\mathrm{TiC}$ particles clustering.

(6) Maximum impact toughness was reported for the iron without Ti-addition and started to deteriorate slightly with further increase in Ti-addition.
(7) Minimum wear rate was reported for the martensitic structure obtained at $980^{\circ} \mathrm{C}$ as compared to the other one treated at $1150^{\circ} \mathrm{C}$.

(8) Optimum abrasion resistance and impact toughness of the investigated white iron ( $16 \% \mathrm{Cr}, 1.3 \% \mathrm{Mo}$, and $2.3 \% \mathrm{Ni}$ ) can be achieved by austenitizing the samples at $980^{\circ} \mathrm{C}$ and adding $1.31 \% \mathrm{Ti}$.

\section{Conflict of Interests}

The authors declare that there is no conflict of interests regarding the publication of this paper.

\section{References}

[1] A. Bedolla-Jacuinde, R. Correa, J. G. Quezada, and C. Maldonado, "Effect of titanium on the as-cast microstructure of a $16 \%$ chromium white iron," Materials Science and Engineering A, vol. 398, no. 1-2, pp. 297-308, 2005.

[2] C. Çetinkaya, "An investigation of the wear behaviours of white cast irons under different compositions," Materials and Design, vol. 27, no. 6, pp. 437-445, 2006.

[3] K. Kambakas and P. Tsakiropoulos, "Solidification of high-Cr white cast iron-WC particle reinforced composites," Materials Science and Engineering A, vol. 413-414, pp. 538-544, 2005.

[4] J. Wang, C. Li, H. Liu et al., "The precipitation and transformation of secondary carbides in a high chromium cast iron," Materials Characterization, vol. 56, no. 1, pp. 73-78, 2006.

[5] Kishore, P. Sampathkumaran, and S. Seetharamu, "Erosion and abrasion characteristics of high manganese chromium irons," Wear, vol. 259, no. 1-6, pp. 70-77, 2005.

[6] H.-S. Yang, W. Jun, B. L. Shen, H. H. Liu, S. J. Gao, and S. J. Huang, "Effect of cryogenic treatment on the matrix structure and abrasion resistance of white cast iron subjected to destabilization treatment," Wear, vol. 261, no. 10, pp. 1150-1154, 2006.

[7] X. Zhi, J. Xing, H. Fu, and Y. Gao, "Effect of fluctuation and modification on microstructure and impact toughness of 20 wt.\% Cr hypereutectic white cast iron," Materialwissenschaft und Werkstofftechnik, vol. 39, no. 6, pp. 391-393, 2008.

[8] P. Aungsnpatoon, S. Inthidech, P. Sricharoenchai, and Y. Matsubara, "Subcritical heat treatment behaviour of hypereutectic high chromium cast iron with molybdenum," in Proceedings of the 10th Asian Foundry Congress (AFC '10), pp. 203-208, Nagoya, Japan, 2008.

[9] J. T. H. Pearce, "Examination of $\mathrm{M}_{7} \mathrm{C}_{3}$ carbides in high chromium cast irons using thin foil transmission electron microscopy," Journal of Materials Science Letters, vol. 2, no. 8, pp. 428-432, 1983.

[10] G. Laird, R. Gundlach, and K. Rohrig, Abrasion-Resistant Cast Iron Handbook, AFS, Carmi, Ill, USA, 2000.

[11] A. Bedolla-Jacuinde, R. Correa, I. Mejía, J. G. Quezada, and W. M. Rainforth, "The effect of titanium on the wear behaviour of a 16\%Cr white cast iron under pure sliding," Wear, vol. 263, no. 1-6, pp. 808-820, 2007.

[12] K. M. Ibrahim and A. A. Nofal, "Effect of titanium addition on structure and properties of the as-cast high Cr-Mo white iron," International Journal of Materials Research, vol. 103, no. 3, pp. 362-370, 2012. 
[13] S. D. Carpenter, D. Carpenter, and J. T. H. Pearce, "XRD and electron microscope study of an as-cast $26.6 \%$ chromium white iron microstructure," Materials Chemistry and Physics, vol. 85, no. 1, pp. 32-40, 2004.

[14] M. K. Vidyorthi, A. K. Ghose, and I. Chakrabarty, "Effect of deep cryogenic treatment on the microstructure and wear performance of $\mathrm{Cr}-\mathrm{Mn}-\mathrm{Cu}$ white cast iron grinding," Cryogenics, vol. 58, pp. 85-92, 2013.

[15] R. Reda, A. A. Nofal, K. M. Ibrahim, and A. A. Hussien, "Microstructure-wear performance relationship of hypoeutectic 15\% Cr-2\% Mo white iron," International Journal of Material Research, vol. 103, pp. 838-846, 2012.

[16] R. Reda, A. Nofal, K. Ibrahim, and A.-H. Hussien, "Structural refinement of $15 \% \mathrm{Cr}-2 \%$ Mo white irons," Key Engineering Materials, vol. 457, pp. 231-236, 2011.

[17] J. Hufenbach, K. Kunze, L. Giebeler et al., "The effect of boron on microstructure and mechanical properties of high-strength cast FeCrVC," Materials Science and Engineering A, vol. 586, pp. 267-275, 2013.

[18] M. Filipovic, Z. Kamberovic, M. Korac, and M. Gavrilovski, "Microstructure and mechanical properties of Fe-Cr-C-Nb white cast iron," Materials and Design, vol. 47, pp. 41-48, 2013.

[19] A. F. Farah, O. R. Crnkovic, and L. C. F. Canale, "Heat treatment in high $\mathrm{Cr}$ white cast iron $\mathrm{Nb}$ alloy," Journal of Materials Engineering and Performance, vol. 10, no. 1, pp. 42-45, 2001.

[20] R. J. Chung, X. Tang, D. Y. Li, B. Hinckley, and K. Dolman, "Effects of titanium addition on microstructure and wear resistance of hypereutectic high chromium cast iron Fe-25wt.\%Cr4wt.\%C," Wear, vol. 267, no. 1-4, pp. 356-361, 2009.

[21] M. M. Arikan, H. Çimenoğlu, and E. S. Kayali, "Effect of titanium on the abrasion resistance of $15 \mathrm{Cr}-3 \mathrm{Mo}$ white cast iron," Wear, vol. 247, no. 2, pp. 231-235, 2001. 

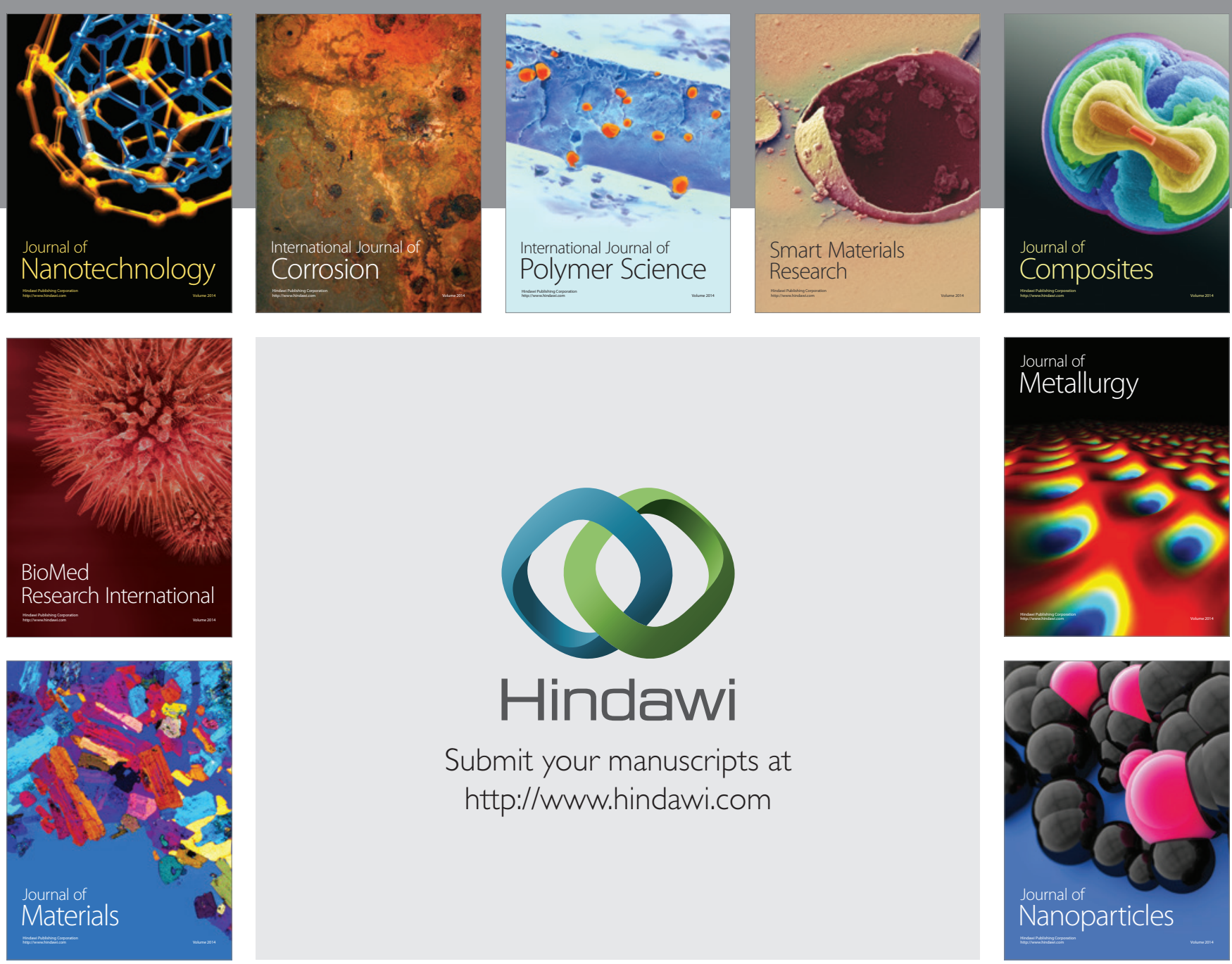

Submit your manuscripts at http://www.hindawi.com
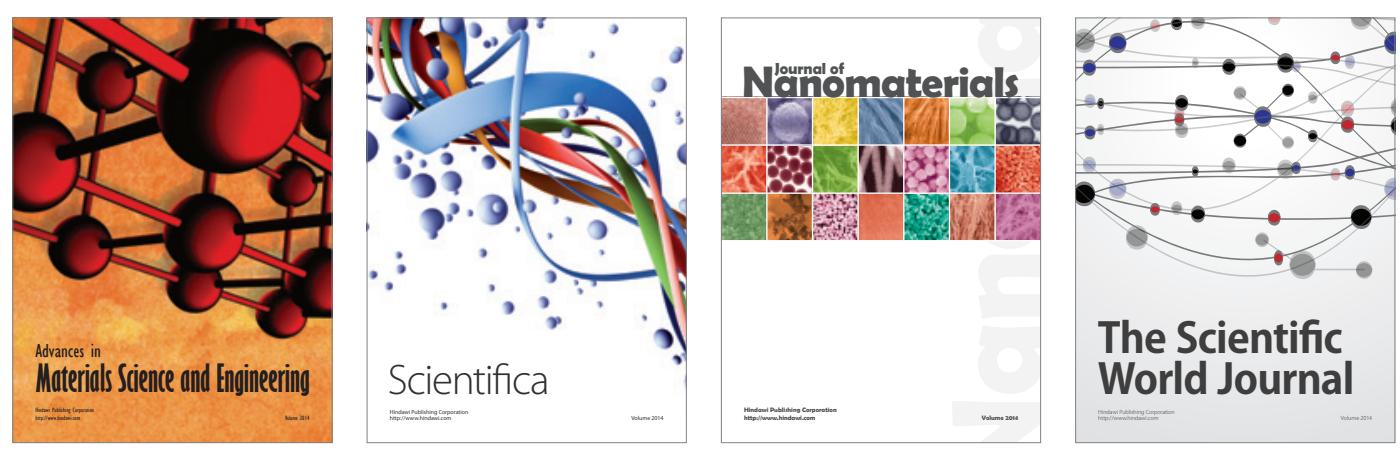

\section{The Scientific World Journal}
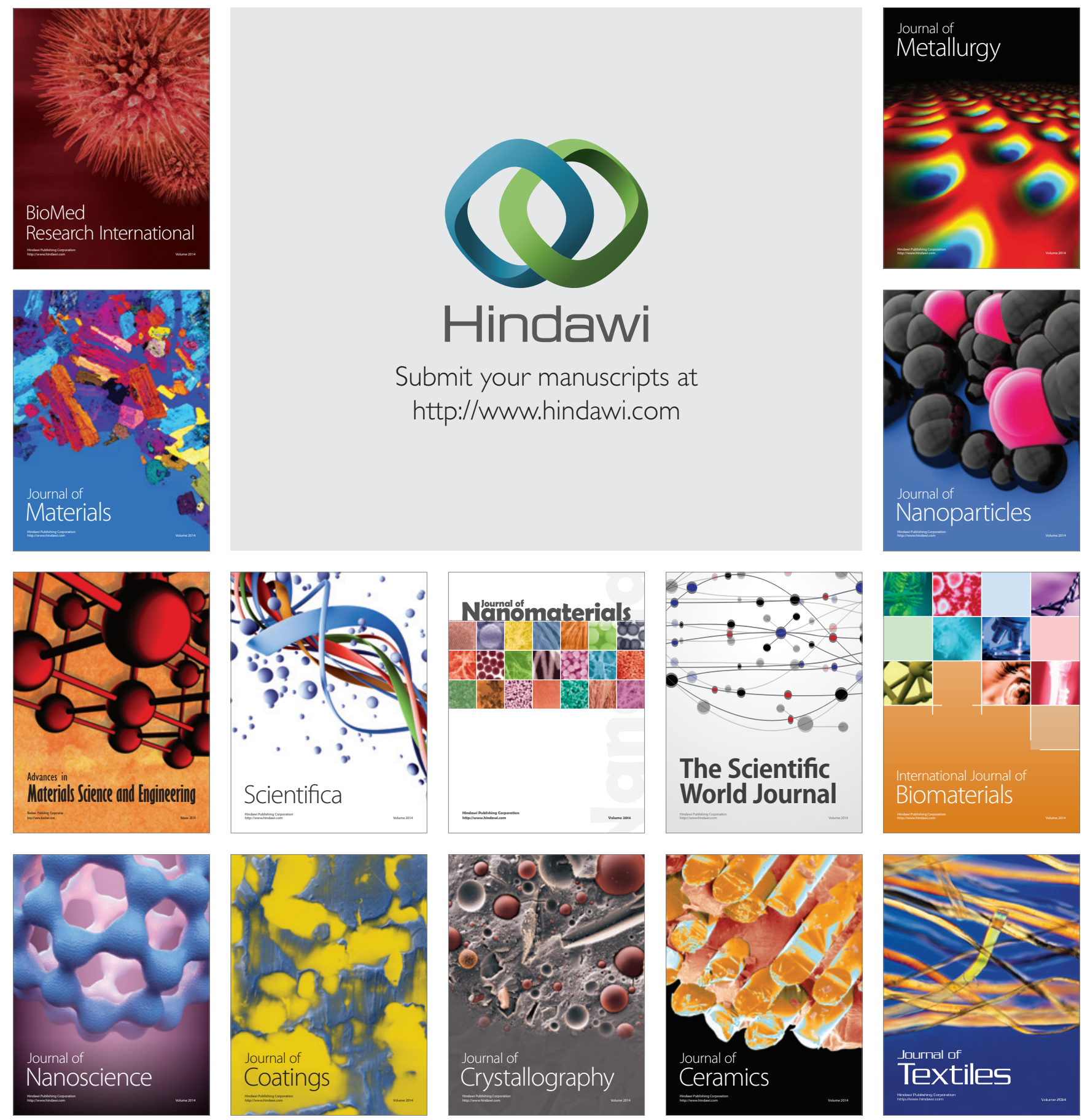